\title{
Lutzomyia longipalpis and the eco-epidemiology of American visceral leishmaniasis, with particular reference to Brazil - A Review
}

\author{
Ralph Lainson/ ${ }^{+}$, Elizabeth F Rangel* \\ Departamento de Parasitologia, Instituto Evandro Chagas, Av. Almirante Barroso 492, 66090-000 Belém, PA, Brasil \\ *Departamento de Entomologia, Instituto Oswaldo Cruz-Fiocruz, Rio de Janeiro, RJ, Brasil
}

An historical review is given of American visceral leishmaniasis $(A V L)$, with particular reference to the ecoepidemiology of the disease in Brazil. Following the first records of AVL in this country, in 1934, the sandfly Lutzomyia longipalpis (Lutz and Neiva, 1912) was incriminated as the principal vector. It is now generally accepted, however, that there exist a number of cryptic species under the name of Lu. longipalpis s.l. and that variations in the quantity of the vasodilatory peptide maxadilan in the saliva of flies from different populations of Lu. longipalpis s.l., may account for the variable clinical manifestations of AVL seen in different geographic regions. Distribution of AVL has been shown to extend throughout most of South and Central America, with the domestic dog serving as the principal reservoir of infection for man. However, while one hypothesis suggests that the causative parasite is Leishmania infantum, imported from Europe with the Portuguese and Spanish colonists, the demonstration of a high rate of benign, inapparent infection in foxes in Amazonian Brazil raised an opposing suggestion that the parasite is indigenous to the Americas. Recent reports of similar infections in native marsupials, and possibly rodents, tend to support this view, particularly as Lu. longipalpis is primordially a silvatic sandfly. Although effective control measures in foci of the disease will diminish the number of canine and human infections, the presence of such an enzootic in a variety of native animals will render the total eradication of AVL unlikely.

Key words: Lutzomyia longipalpis - sandflies - American visceral leishmaniasis - eco-epidemiology - Brazil

Early history: studies in the states of Sergipe, Pará, and Ceará

Following the first description of the sandfly Lutzomyia longipalpis Lutz and Neiva, 1912, in an indeterminate locality in Brazil, interest in this insect remained largely entomological until the mid-1930s. In 1934, however, Henrique Penna used the viscerotome to examine liver samples from persons who were suspected to have died from yellow fever in various rural localities in Brazil, and found that 41 of these deaths were, in fact, due to visceral leishmaniasis. His results suggested the major foci of the disease to be in the northeastern states, particularly in Ceará, and Carlos Chagas, at that time Director of the Instituto Oswaldo Cruz in Rio de Janeiro, sent his son Evandro Chagas to investigate the epidemiology. His first study was made in Sergipe where, in addition to giving the first clinical description of a living case of American visceral leishmaniasis (AVL) in Brazil, he made the important observation that the most frequent blood-sucking insect in and around the patient's house was the phlebotomine sandfly Lu. longipalpis (Chagas 1936).

Evandro Chagas was appointed head of a Commision set up in 1936 to continue his studies and, in view of the higher prevalence of AVL in the Northeast, it was there that he wished to work. Perversely, the only state govenor

Financial support: Wellcome Trust, London

+Corresponding author. E-mail: ralphlainson@iec.pa.gov.br

Received 13 October 2005

Accepted 2 December 2005 who offered the necessary financial and logistic back-up was Da Gama Malcher of Pará in the North of Brazil, where the number of recorded cases was low, and a huge old colonial-style mansion was made available for conversion into the Commision's laboratories, which received the imposing name of "The Institute of Experimental Pathology for the North" (IPEN).

Working in the rural areas of Abaetetuba and Moju, where cases of AVL were recorded by Penna, the Commision uncovered more cases of the disease in both humans and dogs (Chagas et al. 1938). Once more Lu. longipalpis was shown to be the principal man-biting insect in and around the houses of the infected persons, and this sandfly became the major suspect as the vector. It was concluded that the disease was essentially rural and only occurred in the close vicinity of forest or copses. For this reason it was suggested that the origin of the causative parasite, named as Leishmania chagasi by Cunha and Chagas (1937), was in some wild animal. The Commission's hope of confirming the role of $L u$. longipalpis as the vector and indicating the wild animal reservoir were dashed in 1940, however, when the tragic death of their leader Evandro Chagas in a mid-air plane collision put an abrupt end to their epidemiological studies. Although the IPEN was renamed "Instituto Evandro Chagas" in his honour, his little band of dedicated workers never recovered fully from the loss of their brilliant and colourful leader, and research on the epidemiology of visceral leishmaniasis in Brazil went into steady decline.

A rude awakening to the real importance of AVL in Brazil did not occur until 1953, when over 100 inhabitants of the small town of Sobral, Ceará, died in a severe out- 
break which jolted the health authorities into activity. Another epidemiological enquiry was organized, involving three prominent figures in Brazilian tropical medicine - JE Alencar, and the married couple LM Deane and MP Deane who had formed part of the Evandro Chagas team in Pará. In Ceará they made two vitally important findings: heavy flagellate infections of what they considered to be promastigotes of $L$. (L.) chagasi in wild-caught specimens of Lu. longipalpis (Deane \& Deane 1954a), and the natural infection of foxes with that parasite (Deane $\&$ Deane 1954b). The foxes were identified as Lycalopex vetulus, but evidence exists that they were more likely to have been Cerdocyon thous (Courtenay et al. 1996). Infections in Lu. longipalpis were readily obtained when these sandflies were experimentally fed on an infected fox (Deane \& Deane 1954c).

By 1955, Alencar and the Deanes had recorded nearly 1000 new cases of human AVL in Ceará and neighbouring northeastern states. They noted that these occurred in the humid, wooded foothill valleys (boqueiros), and not in the dry lowland plains (sertões) or on the exposed slopes of the hills where the arid conditions and strong winds were unfavourable for Lu. longipalpis. Dogs suffered as badly as man from the infection: that they were the major reservoir of the human disease was clearly indicated by the high rate of canine infection and the ease with which Lu. longipalpis could be infected when fed on infected dogs. On the other hand, it was found that man was a somewhat poor source of the parasite for Lu. longipalpis when these were fed on infected patients (Deane 1956).

\section{Distribution of AVL}

Human visceral leishmaniasis was soon shown to have a very wide distribution throughout Latin America, extending from Mexico in the north to Argentina in the south.

Up to 1984 it was estimated, however, that over $90 \%$ of the recorded cases in the New World were from Brazil, and of a total of 8959 cases registered in this country 7882 were from the Northeast and 992 from the Southeast (Deane \& Grimaldi 1985). Considering inadequacy of diagnosis and a general reluctance in permitting autopsies in the more remote rural communities, these figures are likely to have been considerably higher. To date, the distribution of AVL in Brazil includes the states of Alagoas, Bahia, Ceará, Distrito Federal, Espírito Santo, Goiás, Maranhão, Mato Grosso, Mato Grosso do Sul, Minas Gerais, Pará, Paraíba, Pernambuco, Piauí, Rio de Janeiro, Rio Grande do Norte, Roraima, Sergipe, São Paulo, and Tocantins.

\section{Taxonomic position and origin of the aetiologic agent of AVL}

The name Leishmania chagasi Cunha and Chagas, 1937 long remained in use in spite of considerable debate regarding the origin of the parasite and its taxonomy. Thus, Lainson and Shaw $(1987,1998)$ gave their reasons for considering the parasite as indigenous to the Americas, with an origin in native wild animals, particularly foxes, whereas Killick-Kendrick (1985) and Rioux et al. (1990) favoured the view that it was in fact Leishmania infantum which had been imported into Latin America during the
Portuguese and Spanish colonization of that continent. Similarities in the enzyme profiles of stocks of $L$. chagasi and $L$. infantum led Lainson et al. (1981) to suggest that taxonomic separation of the two parasites "would best be at subspecific level", but following their studies on the genomic diversity of members of the Leishmania donovani complex, Mauricio et al. (1999) considered that there were no grounds for any separation. More recently Lainson and Rangel (2003) and Lainson and Shaw (2005) have used the subspecific names of $L$. infantum infantum and $L$. infantum chagasi in consideration of previous claims that distinct differences exist between the two organisms based on the kDNA fragment patterns using the restriction endonuclease digestion technique (Jackson et al. 1982, 1984); comparison of radioiodinated surface proteins of their promastigotes, and monoclonal antibodies generated against promastigote surfaces (Santoro et al. 1986); and comparative radiorespirometry studies (Decker-Jackson \& Tang 1982). Recently, Martinez et al. (2003) claimed to differentiate $L$. infantum and $L$. chagasi by the Random Amplification Polymorphic DNA technique (RAPD) and a single 10-mers long primer.

The origin of AVL thus remains debatable.To account for the immense geographic distribution of the disease following the introduction of $L$. infantum and adaption of the parasite to $\mathrm{Lu}$. longipalpis, one must postulate either that this took place at very many points on the Latin American continent, or that there was a rapid spread of the parasite throughout South and Central America. Such a spread from a few isolated points of introduction by way of Lu. longipalpis seems unlikely, due to the limited flight range of phlebotomines in general (Alexander 1987), the fairly static nature of populations of this insect and the improbability of infected adult sandflies being unintentionally transported by man. Again, although spread by way of infected dogs might take place in a given country, it remains unlikely that this could account for the presence of the parasite in almost the whole of the Latin American continent in such a short time.

\section{Lu. longipalpis: the major vector of AVL}

The coincidental distribution of Lu. longipalpis and AVL throughout most of Central and South America greatly strengthened the Deanes' conviction that this was the major vector of the disease. Strangely enough, however, although $\mathrm{Lu}$. longipalpis is perhaps the most easily colonized of all sandflies in the laboratory, repeated attempts to experimentally transmit the parasite by the bite of this insect failed. Appropriately enough it was in the Instituto Evandro Chagas, where so much of the early history of AVL began, that the chain of evidence incriminating this sandfly was finally completed when five separate transmissions to hamsters were obtained by the bites of experimentally infected laboratory-bred $\mathrm{Lu}$. longipalpis (Lainson et al. 1977a). The same laboratory (Lainson et al. 1984, 1985) studied a serious outbreak of AVL in the outskirts of Santarém, Pará, where they found this sandfly to be the only species consistently present in and around houses with human and canine infections. Large numbers were captured in the back-yard of one house and fed on clean hamsters, four of which subsequently developed 
fulminating infections. Dissections of the sandflies used in this experiment indicated an infection-rate of $7 \%$, and 16 isolates were identified as $L$. (L.) chagasi on enzyme profiles and by monoclonal antibodies. This transmission by the bites of naturally infected $\mathrm{Lu}$. longipalpis provided the most conclusive proof possible of the role of this sandfly as a major vector of AVL.

\section{The ecology of $\mathbf{L u}$. longipalpis: a sylvatic origin}

Most early studies on AVL in Brazil were made in the sparsely forested northeastern states, or in other parts of the country that have suffered considerable deforestation and, as a result, there developed the tendency to think of the disease only as one which involves the dog and Lu. longipalpis in a domestic environment. Observations in the Amazon region of Brazil (Chagas et al. 1938, Lainson et al. 1986, Ryan et al. 1986c), however, indicated that $L u$. longipalpis is primordially a sylvatic species and that it can still be captured in remote primary forest that is far from human habitation. In Northern Brazil this is particularly evident along the length of newly opened roads that pass through forested areas. Primitive houses, inevi- tably with dogs, chicken houses and other animal shelters, are rapidly thrown up along their length, in very close proximity to the forest edge. Lu. longipalpis females have catholic feeding habits and quickly invade such habitations: thus, in an epidemiological investigation of cases of AVL along the forest-fringed Igarapé Miri-Tucuruí highway this sandfly was found in the chicken houses of numerous widely separated houses only 18 months after the road had been opened (Lainson, Shaw, Silveira \& Souza, unpublished observations). Finally, even more conclusive evidence came from studies in the municipality of Salvaterra, Island of Marajó, Pará, in a focus of AVL (Lainson et al. 1990). Using CDC light-traps variously placed over caged chicken, a fox, and sawdust impregnated with the urine and faeces of a fox, attempts were made to capture Lu. longipalpis in a pocket of residual primary forest, the back-yard of a house some $500 \mathrm{~m}$ distant, and neighbouring open savanna. During the dry season, 80 trapping-nights in the forest produced a total of 47 of these sandflies, consisting of 22 males and 25 females: none were caught following 14 captures in the savanna, and 2 captures in the back-yard of the house

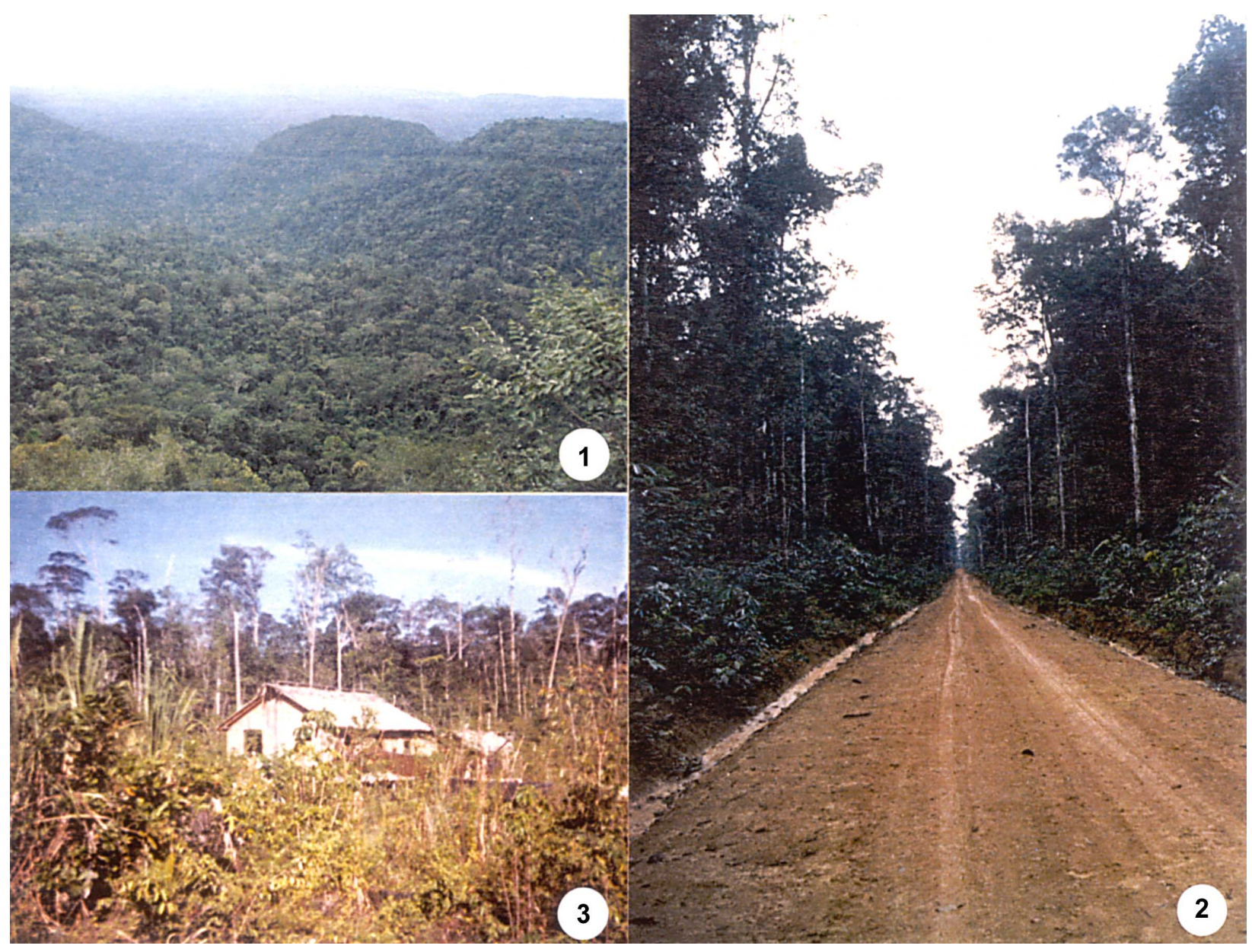

Figs 1-3: stages in the development of foci of leishmaniasis in Pará, Amazonian Brazil. Fig. 1: primary forest in the Serra dos Carajás, where the sandfly vector Lutzomyia longipalpis forms part of the phlebotomine fauna. Figs 2, 3: the margins of new roads cut though the forest (Fig. 2) are soon accupied by rustic houses (Fig. 3), with a subsequent infestion of chicken houses and other animal shelters by $L u$. longipalpas coming from the adjacent forest. 
provided only one male and four females. During the wet season the results were much more impressive: 32 trapping-nights in the forest provided 1161 (463 males and 698 females); 26 captures in the savanna gave a total of 4 (one male and 3 females); and 24 captures in the backyard of the house produced a total of 1274 (572 males and 702 females). From this and other studies it was clear that the natural savanna is an unattractive breeding-site for Lu. longipalpis. On the other hand the large numbers of this sandfly caught in the patch of forest, and the marked association of males and females during both the dry and wet seasons, strongly suggested this to be an important breeding-site. Galati et al. (2003) recently reported the capture of Lu. longipalpis in the forest environment in the state of Mato Grosso do Sul, Brazil. It remains to be determined, however, if the peridomestic accumulation of this sandfly is entirely due to their migration from the sylvatic habitat or, at least in part, to the establishment of a secondary peridomestic breeding-site.

The discovery of the latter would be a significant step forward in the control of AVL, but to date all available evidence suggests that the immature stages of $L u$. longipalpis are thinly dispersed, and not concentrated in any particular microhabitat (Deane 1956). In Salvaterra, on the Island of Marajó, the results of an examination of soil removed within and around a small, heavily infested chicken house suggested that the sandflies were not breeding in that microhabitat, but had migrated to the chicken house from elsewhere (Dye \& Quinnell, pers. commun.). It has been shown, in the laboratory, that the male produces a pheromone which attracts the female from a substantial distance (Morton \& Ward 1989), leading these authors to suggest that the attraction of host odour and male pheromone worked together at the same time and synergistically. On the other hand, following their observations on the progressive infestation of newly con- structed chicken houses by Lu. longipalpis, Dye et al. (1991) and Quinnell and Dye (1994a) were led to the conclusion that the females, accompanied by some males, are at first attracted by host odour and latterly by the pheromone. It was noted, however, that whereas the males tended to remain longer in the chicken houses, most of the females did not rest there during the day.

That Lu. longipalpis females feed readily on the domestic chicken suggests that wild birds are likely to be among their sylvatic hosts. This sandfly's concentration in chicken houses is of considerable epidemiological importance, because it is not customary to spray these with insecticides during antimalarial campaigns - which still remain the principal, indirect control of AVL.

Following experimental studies on the peridomestic distribution of Lu. longipalpis in Salvaterra, Island of Marajó, Quinnell and Dye (1994a,b) concluded that this sandfly tends to congregate at sites outdoors, including animal sheds, where leks can most easily form on abundant, stationary (sleeping) hosts. The flies are much less frequently encountered within houses and, as most dogs sleep outdoors, this probably accounts for a much higher infection-rate of AVL in dogs than in man. It was also suggested that humen exposure to the bites of $L u$. longipalpis was greatest in poorly constructed houses with abundant holes in the walls and the roof.

\section{The Lu. longipalpis complex}

Mangabeira (1969) first drew attention to small morphological differences between male examples of $L u$. longipalpis from Ceará, Northeast Brazil, and others from Pará, North Brazil, and Lainson and Shaw (1979) suggested that the presence of "....a Lu. longipalpis complex of very similar sandflies.... may account for certain anomalous situations" and that "a taxonomic revision is needed of....Lutzomyia longipalpis"

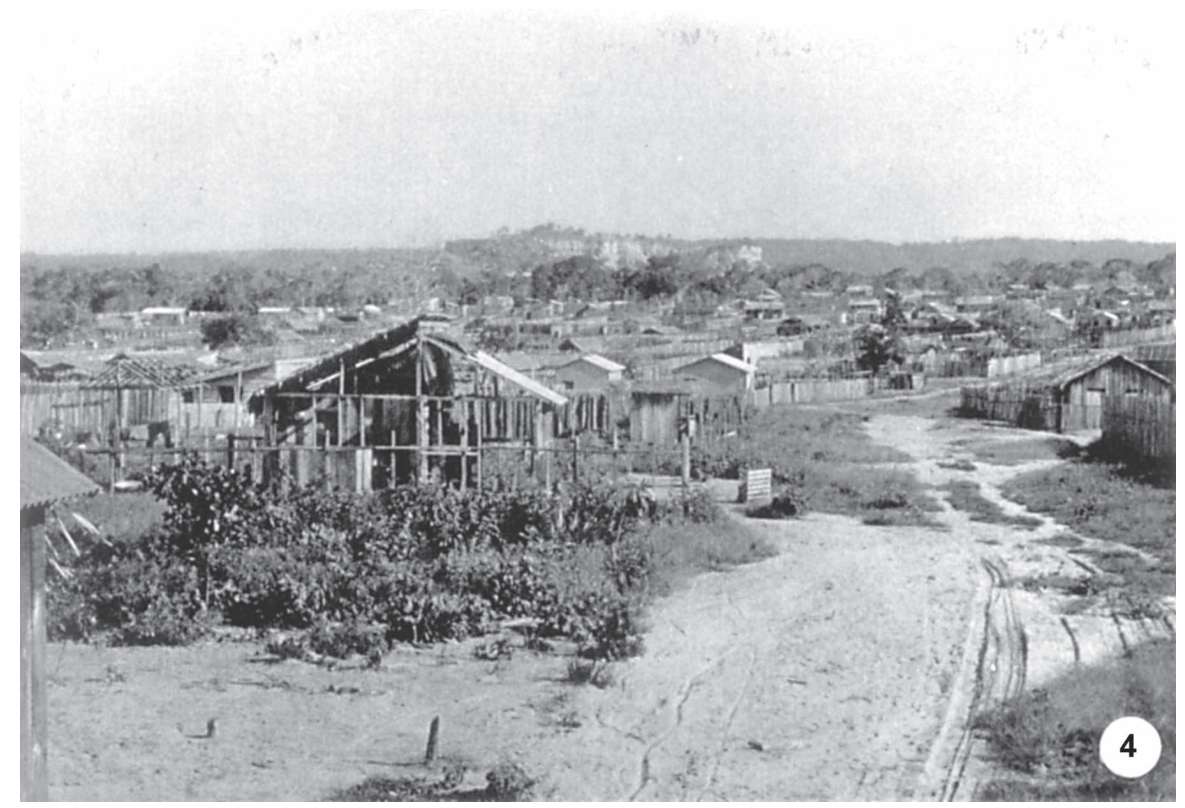

Fig. 4: final stage in the formation of a focus of Amazonian visceral leismaniasis. Disorganised growth of a shanty-town, high density of the sandfly vector and an abundance of dogs. Outskirts of Santarém, Pará, North Brazil. 
Ward et al. (1983) confirmed Mangabeira's finding; namely, that the male flies from Pará had a pair of white spots on the 4th abdominal tergite, whereas those from Ceará had two pairs of spots on the 3rd and 4th tergites. Furthermore, they showed that the two forms were sexually isolated, suggesting that they represented two cryptic species. It was also suggested that this might account for epidemiological differences in AVL in the two geographic areas (Ward et al. 1985).

By use of the electron-microscope, Lane et al. (1985) showed that the tergal spots were in fact the site of pheromonal glands, and further studies (Ward et al. 1988, Hamilton et al. 1996) went on to show that the different populations of $\mathrm{Lu}$. longipalpis produced different pheromones and that the female flies could differentiate the correct one. Correct mating depended on different "songs" produced by the vibrating wings of the males.

More evidence of the existence of a species complex of Lu. longipalpis s.l. was offered by Crampton et al. (1989), who prepared a DNA probe which was specific for a Bolivian population of this sandfly, and Lanzaro et al. (1993) who compared examples from Costa Rica, Colombia, and Brazil by enzyme electrophoresis and cross-breeding experiments. They concluded that these populations were of three distinct species, but refrained from using any new specific names. Mutebi et al. (2002) added support to this conclusion by demonstrating genetic differentiation of these populations and this was also demonstrated in populations of the sandfly in Venezuela (Arrivillaga et al. 2000). Further evidence for the presence of cryptic species within a Lu. longipalpis complex has been provided by numerous other workers (Dujardin et al. 1997, Lampo et al. 1999, Uribe, 1999, Yin et al. 1999, Arrivillaga \& Feliciangeli 2001, Soto et al. 2001, Arrivillaga et al. 2002, 2003).

The existence of such cryptic species in Brazil was disputed by Mukhopadhyay et al. (1998), Mutebi et al. (1999), Azevedo et al. (2000), and Arrivillaga et al. (2002, 2003) who considered that there is only a single species in that country, based on a study of several widely separated populations for genetic variability in biochemical characters. They felt that the reasons for any epidemiological variations in AVL should be sought elsewhere. In favour of this view, a recent study of Lu. longipalpis populations from six locations in a transect across eastern Brazil by mitochondrial cytochrome $b$ gene sequence analysis suggested that sequence divergence also did not adequately indicate cryptic species (Hodgkinson et al. 2003). On the other hand, comparison of the courtship "songs" has detected differences of song pattern between Brazilian populations of Lu. longipalpis, and these were consistent with the level of molecular divergence, found at the cacophony locus, among the different populations (Bottechia et al. 2004, Souza et al. 2004). These groups of workers suggest that their findings, together with other evidence, does suggest the existence of a cryptic species-complex under the name of $L u$. longipalpis in Brazil, with as many as four sibling species (Souza et al. 2004). Among the additional evidence, for example, populations of this sandfly from Jacobina (Bahia), Lapinha (Minas Gerais), and Natal (Rio Grande do
Norte) had been differentiated on genetic grounds (Bauzer et al. 2002), and Maingon et al. (2003) produced genetic evidence of the existence of two sibling species of $L u$. longipalpis, that produce distinct male sex pheromones in Sobral, Ceará, Northeast Brazil. Finally, Watts et al. (2005) investigated the phylogeographic pattern of variation at microsatellite loci among 11 populations from Brazil and Venezuela, related to their male pheromone. They concluded that "Temporal genetic differentiation was mostly not significant at the same site. Spatial genetic differentiation was, however, strong, although there was only a weak relationship between genetic differentiation and the geographic distance separating the samples.... Geographic separation explained a much greater.... percentage of the genetic differences among populations when samples with the same pheromone type were analyzed separately." A cluster analysis showed 5 groups: Lu. cruzi (Brazil) and Lu. pseudolongipalpis (Venezuela) as separate species, two Venezuelan and Brazilian groups, and a very distinct cluster of Brazilian cembrene populations.

Most authors have cautiously refrained from giving names to examples of "cryptic species", and it has rightly been asked if these different populations might not simply indicate the initiation of a speciation process rather than the existence of valid species (Bottecchia et al. 2004). It has also been questioned as to whether Lu. longipalpis ".....is a highly polymorphic and geographically variable species, but not a species complex" (Bauzer et al. 2002).

Arrivillaga and Feliciangeli (2001), however, gave the name of Lutzomyia pseudolongipalpis to a sandfly in Venezuela. The adults are apparently morphologically indistinguishable from those of Lu. longipalpis, but the larvae are morphologically distinct. In addition, the adult fly's biting activity was shown to be continuous throughout the night, unlike that of two populations of Venezuelan Lu. longipalpis which was found to be at its greatest before $23.00 \mathrm{~h}$ and to steadily decrease from that time onwards (Feliciangeli et al. 2004). Arrivillaga et al. (2003) made phylogenetic analyses of thirty-one populations of Lu. longipalpis s.l. originating throughout this species' geographic range, using seven isozyme loci and genes in the mitochondrial genome. The analyses revealed four distinct clades which, it was considered, supported the existence of four species. These had distinct geographic ranges, defined as (1) Brazil (Lu. longipalpis sensu stricto); (2) Laran (Northwestern Venezuela populations); (3) cis-Andean-Colombia; and (4) trans-Andean-Central American populations. The Brazilian clade was represented by 11 populations sampled throughout this country, including the areas in which Lu. longipalpis was originally described; the sandfly of the Laran clade $=L u$. pseudolongipalpis from Northwest Venezuela; the cisAndean clade consisted of Colombian populations in Bucaramanga, Palo Gordo, Neiva, Durania, and a population from Pacaraima, North Brazil (a mountainous area in Roraima, on the borders of Venezuela and Guyana); the trans-Andean clade included 11 populations from various parts of Central America. The authors have proposed to prepare descriptions and new specific names for the sandflies of the latter two clades. 
Differing opinion will doubtless continue concerning the criteria needed before a considered "cryptic species" can be given specific rank, but intrinsic reproductive isolation, as demonstrated by cross-breeding experiments, must surely be high on the list. In this connection, the work on the sandfly's mating "song" is particularly interesting, as the vocalization of the males of a number of insects appears to be the most important barrier isolating the different species (Imms 1964, Perdeck 1957).

The existence of a complex of cryptic species, under the name of Lu. longipalpis s.l., helps considerably in explaining why very different clinical manifestations of AVL exist in Latin America, especially when this is considered in the light of studies on the nature of the saliva of Lu. longipalpis s.l. from widely separated geographical areas.

The influence of the saliva of Lu. longipalpis s.l. on infection of man with $L$. infantum chagasi

Although infection with $L$. $i$. chagasi is predominately associated with a visceral disease, the same parasite has been shown to produce only non-ulcerative cutaneous lesions in Costa Rica (Zeledón et al. 1989), while in Honduras it may cause both visceral and cutaneous leishmaniasis in the same focus (Ponce et al. 1991). The saliva of Lu. longipalpis contains a potent vasodilatory peptide, 'maxadilan' (Lerner et al. 1991). In experiments investigating the possible influence of the sandfly's saliva on the course of human infection with L. i. chagasi, Warburg et al. (1994) fed Lu. longipalpis s.l. of Brazilian, Colombian and Costa Rican origin on the arms of volunteers. They found that the measurements of the resulting erythemas at the sites of the bites correlated well with the levels of maxadilan in the sandflies from the three geographical areas. Saliva from the Brazilian colony was the most potent, while that from the Colombian flies was less so. Saliva from the Costa Rican specimens had very little maxadilan, a very low vasodilatory activity and produced negligible erythema: when mixed with promastigotes of Leishmania major and inoculated into the foot-pads of mice it strongly enhanced proliferation of cutaneous lesions. On the other hand, similar inoculations of mixtures of promastigotes and saliva from Colombian and Brazilian $\mathrm{Lu}$. longipalpis exacerbated the development of cutaneous lesions to a lesser degree. It was suggested that some of the variability in the clinical presentations of $L$. $i$. chagasi infections may be due to the different composition of the saliva of the sandfly, presumably accounting for the manifestation of L. i. chagasi infection in man as either a visceral or a cutaneous disease. The significance of these findings regarding the nature of infections in wild or domestic reservoir hosts in foci of human cutaneous and/or visceral leishmaniasis due to this parasite remains to be studied. A cutaneous lesion due to $L$. $i$. chagasi has been reported in a patient from the state of Rio de Janeiro, Brazil (Oliveira et al. 1986). Unlike those described in Costa Rica and Honduras, however, the lesion was ulcerative, and cutaneous manifestations of infection with this parasite in Brazil would appear to be a rarity.

\section{Other possible vectors of $L$. $i$. chagasi in Brazil and neighbouring countries}

The assumption that $L u$. longipalpis s.l. was the sole sandfly vector of $L$. $i$. chagasi throughout the whole geographical range of AVL was to persist for over 50 years. Suspicions were raised, however, that other species of sandflies might be involved in Venezuela when cases of the disease were recorded in the apparent absence of this sandfly.

Thus, Potenza and Anduze (1942) were unable to find $\mathrm{Lu}$. longipalpis in two districts of the state of Bolivar, where two cases of infantile visceral leishmaniasis had been diagnosed, and Pifano and Romero (1964) suggested that $L u$. evansi (Nuñez-Tovar) might be an alternative vector in a focus of AVL in the Turmiquire hills, state of Sucre, Venezuela, where Lu. longipalpis was seemingly absent. A further 26 years were to elapse, however, before this suspicion was substantiated, when Travi et al. (1990) showed that $87 \%$ of the sandflies captured in a focus of AVL in the Córdoba Department of Colombia were $L u$. evansi and that one of these flies was infected with $L$. $i$. chagasi, as identified by isolation of the parasite and its characterization by isoenzyme electrophoresis. In further studies in north Colombia, promastigotes were found in nine more specimens of Lu. evansi and the parasite again identified as L. i. chagasi on two occasions (Travi et al. 1996). This, the presence of Lu. evansi in peridomestic and intradomestic habitats throughout the year, and the apparent absence of Lu. longipalpis, led to the conclusion that $L u$. evansi is the principal vector of AVL in that region of Colombia, although elsewhere the vector has been shown to be Lu. longipalpis (Ferro et al. 1995). Recently, in Carabobo state, Venezuela, Aguilar et al. (1998) recorded the presence of promastigotes in a single specimen of Lu. evansi captured in an area endemic for AVL, and among 1757 sandflies caught in and around houses $72.9 \%$ were $L u$. evansi and only $1.3 \% \mathrm{Lu}$. longipalpis. Finally, Feliciangeli et al. (1999) used k-DNA restriction analysis to show high homologies between the culture forms of the parasite from $L u$. evansi and a standard stock of $L$. i. chagasi. These findings regarding $L u$. evansi raise two major questions: firstly, whether or not it may be an alternative vector of AVL in other parts of this sandfly's geographical range, and secondly if there exist other alternative vectors. In addition to Colombia and Venezuela, Lu. evansi has been recorded in Costa Rica, Honduras, Nicaragua, El Salvador, Guatemala (Young \& Duncan 1994), and Mexico (Ibáñez-Bernal et al. 2004). Evidence suggests that adaptation of $L$. i. chagasi to $L u$. evansi is a relatively recent event which is still in progress. Thus, Montoya-Lerma et al. (2003) made a study of the infection-rates and development of $L$. i. chagasi in $L u$. longipalpis and $L u$. evansi in natural and experimental conditions. Experimental infection-rates and the cycle of L. $i$. chagasi in the two flies have shown that parasite colonization, differentiation, attachment to the gut epithelium and migration to the fore-gut were all more frequent and uniform in Lu. longipalpis than they were in Lu. evansi. 
As far as we can ascertain, Lu. evansi has not been found in Brazil, but speculations have been made regarding the possible role of a variety of other sandfly species in the transmission of L. i. chagasi. Oliveira et al. (1959) failed to find Lu. longipalpis in a village in Minas Gerais where there was a high incidence of AVL, and suspicion fell principally on Lu. intermedia and Lu. whitmani. Coelho et al. (1965) were also unable to capture $L u$. longipalpis in a focus of the disease in southwest Goiás, where the most common sandflies were Lu. intermedia, Lu. whitmani, Lu. shannoni, and Lu. (Psychodopygus) davisi. Ryan et al. (1984) recorded heavy promastigote infections in $\mathrm{Lu}$. antunesi captured in a focus of AVL on the Island of Marajó, Pará. Although the organism remained unidentified, its suprapylarian development in the sandfly raised the question as to whether or not it was $L$. i. chagasi. The same authors (unpublished observations) found heavy infestations of $L u$. furcata in pigsties in an area near Belém, Pará, where isolations of $L$. i. chagasi had been made from foxes but where Lu. longipalpis could not be found. Lu. furcata is not anthropophilic but attacks a variety of wild and domestic animals. It could possibly represent, therefore, an alternative vector among such reservoir hosts of $L$. $i$. chagasi as dogs and foxes: experimentally, it has been shown to be capable of transmitting another species of Leishmania, L. (L.) amazonensis (Ryan et al. 1986a).

The female of the sandfly $L u$. cruzi is considered to be morphologically indistinguishable from that of $L u$. longipalpis (Martins et al. 1984), and the two species can only be reliably separated by small differences when comparing the males. To add to the confusion, a distribution overlap makes it difficult to incriminate either species as the vector of AVL in areas where the two are found together. Santos et al. (1998) dissected a large number of sandflies captured in CDC light-traps around houses in a focus of AVL in Corumbá and Ladário, Mato Grosso do $\mathrm{Sul}$, and found promastigotes in 14 female specimens, all with the morphology of Lu. longipalpis/Lu. cruzi. The parasite was identified as $L$. $i$. chagasi by monoclonal antibodies and, in virtue of the apparent absence of males of Lu. longipalpis in their captures, these authors concluded that all the infected flies were $L u$. cruzi and that "......L. cruzi is the vector of Leishmania chagasi in the area of Mato Grosso do Sul, Brazil". Although the evidence for this supposition is strong, it is not yet conclusive, and in a more recent publication Santos et al. (2003) have, in fact, confirmed the presence of $\mathrm{Lu}$. longipalpis in the Corumbá area of study. Until infected females can be conclusively identified as $L u$. cruzi - by way of biochemical methods (Ryan et al. 1986b), by DNA probes (Ready et al. 1991), or after the production of adults by raising them from the eggs of infected flies (Ryan et al. 1987), the role of $L u$. cruzi as a vector of $L$. $i$. chagasi must remain doubtful. Little information exists on the distribution of Lu. cruzi. Young and Duncan (1994) suggest that in Brazil this sandfly is restricted to the state of Mato Grosso do Sul. Santos et al. (1998) suggest that the epidemiology of AVL in the area of Bolivia bordering Mato Grosso do Sul "....certainly should be the same...." : namely, that $L u$. cruzi also occurs in Bolivia. The limited distribution of both $L u$. cruzi and Lu. evansi compared with that of $L u$. longipalpis leaves no doubt regarding the overwhelming importance of the latter as the principal sandfly host of $L$. i. chagasi.

Among other possible "alternative" vectors, $L u$. intermedia and Lu. whitmani must be included. $L u$. intermedia, highly suspected as a vector of $L$. (V.) braziliensis in southeast Brazil, shares a similar habitat to that of Lu. longipalpis, is highly anthropophilic and also known to feed on dogs: in addition, it has been experimentally infected with $L$. i. chagasi (Chagas 1940, Paraense \& Chagas 1940). On the other hand, Lu. intermedia has not been recorded further north than Paraíba, in Alagoa Grande and Areia, and part of Pernambuco in Lagoa dos Gatos, Nazaré, Quipapá, Timbaúba and Vitória de Santo Antão (Martins et al. 1978, Young \& Duncan 1994). Consequently, it cannot be involved as a secondary vector of AVL in the highly endemic areas in Ceará and Piauí, or in the states of Maranhão and Pará. Lu. whitmani sensu stricto is a confirmed vector of $L$. (V.) braziliensis in Northeastern Brazil (Rangel \& Lainson 2003) and, as mentioned above, has been suspected as a vector of AVL in Minas Gerais and Goiás. It is highly anthropophilic and frequently found, together with Lu. longipalpis, in chicken houses and human dwelling places. Regarding transmission in the sylvatic habitat in north Brazil, $L u$. whitmani sensu lato might function as a vector among foxes, but its rarity near houses and its non-anthropophilic habits militates against it being a vector of $L$. i. chagasi to man.

In the Amazon region, suspicion must fall on $L u$. flaviscutellata as a conceivable alternative vector of $L$. $i$. chagasi. It is better known as the major silvatic vector of L. (L.) amazonensis among a variety of rodents and marsupials, but this parasite has been isolated from a fox in Pará (Lainson \& Shaw 1987), indicating that this sandfly does include foxes among its hosts, and these animals are natural hosts of L. i. chagasi. Lu. flaviscutellata is occasionally found invading the peridomestic habitat in areas where isolated cases of Amazonian AVL have been diagnosed (Lainson et al. 1994). It is not greatly attracted to man, however, so its role as a secondary vector, if indeed it exists, would be of minor importance. Souza et al. (2003) were unable to find Lu. longipalpis in 6 of 18 foci of AVL in the municipality of Rio de Janeiro and suggested the participation of other species of sandflies such as $L u$. migonei and $\mathrm{Lu}$. firmatoi. When considering the apparent absence of Lu. longipalpis in such foci of AVL, however, it must be remembered that with the change of rainy to dry season the population density of this sandfly may fall to such an extent that no examples can be found until advent of the next wet season.

\section{Amazonian AVL: indigenous or introduced?}

While there remains little doubt that peridomestic/ intradomestic infestations by $L u$. longipalpis and/or $L u$. evansi originate(d) from sylvatic populations of these sandflies, the origin of $L$. i. chagasi has remained controversial, particularly in the more remote forested areas.

It has been argued that in Brazil the parasite was introduced into the Amazon region by way of infected dogs 
accompanying immigrants coming from major foci of AVL in the northeastern states, such as Ceará and Piauí. At the time of Penna's discovery of human visceral leishmaniasis in Pará in 1934, however, there were no roads linking that state with Northeastern or Southern Brazil. Access was possible only by boat or small aircraft and, at that time, this would have severely limited any migration of families and their dogs to northern Brazil from those regions. Moreover it is highly likely that previous cases of AVL in Pará must have gone undiagnosed long before Penna's chance discovery, and at a time, therefore, when importation of the disease into the forested north of Brazil, in this way, was even more unlikely. Relatively recent eco-epidemiological studies in some areas of northern Pará have shown cases to be sporadic, widely separated and not significantly associated with immigrant families. Furthermore, infections registered in men sleeping in lumber camps in or near forest, and far from fixed habitations, suggested a feral source of the parasite (Lainson, Shaw, Silveira, and Souza, unpublished observations).

In the Old World it has been suggested that the origin of human visceral leishmaniasis, due to parasites of the $L$. (L.) donovani complex, was a rural enzootic in wild canids such as foxes, jackals and wolves, and that it later spread to dogs (Lysenko 1971). Wild canids have been present in South America since the Pleistocene era some 2-3 million years ago, and a similar origin from such animals has been postulated (Lainson 1989). In support of this is the predominantly benign infection commonly found in foxes, which does suggest an ancient well balanced host-parasite relationship, as opposed to the usually virulent nature of infection in the dog. In Venezuela, and doubtless impressed by the Deanes' record of infected foxes in Ceará, Torrealba and Torrealba (1964) inoculated a specimen of Cerdocyon thous with L. $i$. chagasi. The animal showed no signs of infection, but amastigotes were encountered in its bone marrow seven months later. In Amazonian Brazil, workers of the Instituto Evandro Chagas examined 23 C. thous from agricultural land close to both primary and secondary forest on the outskirts of Belém, Pará, and isolated L. i. chagasi from three of them (Lainson et al. 1969, 1987).

None of the animals showed outward signs of infection, and neither canine nor human visceral leishmaniasis had ever been recorded in that locality, which was very sparsely inhabited. Turning their attention to foci of AVL in rural areas of the Island of Marajó, Pará, the same laboratory (Silveira et al. 1982, Lainson et al. 1987) isolated the parasite from 11 of 26 C. thous $(42.3 \%)$ by the inoculation of hamsters with triturates of liver and spleen from these animals. In addition, it was shown that 22 other specimens $(54.6 \%)$ were serologically positive by the indirect fluorescent antibody test (IFAT): none of the parasitologically or serologically positive animals showed signs of infection. A similar occult infection of $C$. thous has also been recorded in a focus of AVL in Corumbá, in the state of Mato Grosso do Sul, Brazil (Mello et al. 1988).

Although the Deanes (1954c) had shown that $L u$. longipalpis could readily be infected when fed on a fox suffering from an acute infection with $L$. $i$. chagasi, it remained to show that apparently healthy foxes with an occult infection could also serve as a source of infection for these sandflies. Lainson et al. (1990) infected laboratory-bred Lu. longipalpis with a fox strain of the parasite by feeding them on a blood-suspended triturate of heavily infected hamster spleen, through a chick-skin membrane. On the sixth day post-infection, and following oviposition, only four of the sandflies remained alive, and attempts were made to feed these on a young fox which was serologically negative at the time of the experiment and for seven weeks previously. Only two of the flies fed on the animal, but subsequent dissection showed them both to be heavily infected. Five weeks later the IFAT titre of the fox was 1: 1280, and when 60 clean Lu. longipalpis were fed on the animal after a further 10 weeks, four of the 54 surviving flies $(7.4 \%)$ showed promastigote infections. Infection of the fox was confirmed by isolation of the parasite from skin, spleen, liver and bone marrow.

\section{Other wild animal hosts of $L$. $i$. chagasi}

Sherlock et al. $(1984,1988)$ isolated L. i. chagasi from two opossums, Didelphis albiventris, captured in a focus of AVL in Jacobina, Bahia, but considered that it was unlikely that this animal represented an important reservoir of the parasite because of the very low infection-rate (two of 84 examined).

Workers in Colombia (Corredor et al. 1989a,b, Travi et al. 1994) registered the isolation of the parasite from the common opossum Didelphis marsupialis following the in vitro culture of spleen, liver and skin in various media and the intraperitoneal inoculation of hamsters. In one focus of AVL the infection-rate of the opossums was as high as $12 / 37$ (32\%), and it was concluded that this animal is an important reservoir of L. i. chagasi. Travi et al. (1998a) followed up these findings by experimentally infecting $D$. marsupialis with both amastigotes and promastigotes of L. i. chagasi (dog strain). No parasites could be detected by culture of the opossums' blood and only very few $L u$. longipalpis were infected when fed on these animals. They nevertheless considered that xenodiagnosis with the sandfly Lu. longipalpis was a more sensitive method for detecting infection than was the polymerase chain reaction (PCR). Travi et al. (1998b) then studied a variety of small mammals captured in both undisturbed and degraded, dry forest in northern Colombia, using the PCR and dot-blot hybridization techniques: they made no attempt to isolate the parasite. Positive PCR/hybridization results for $L$. $i$. chagasi DNA were obtained for 3/21 (14.3\%) D. marsupialis caught in undisturbed forest and $13 / 137$ $(9.5 \%)$ of this animal from the degraded forest. Positive results were also recorded for 3/34 specimens of the rodent Proechimys canicollis from undisturbed forest and in 2/4 from degraded forest, and the authors considered these results to indicate active infections of these rodents with L. $i$. chagasi. No foxes were examined in these surveys, although the authors state that $C$. thous was present in the study areas and "...might contribute to the maintenance of L. chagasi”. The very high percentage of $C$. thous infected in foci of AVL in North Brazil and experimental infection of $\mathrm{Lu}$. longipalpis fed on an infected fox, together suggest this to be highly likely. 
As a result of the positive PCR-hybridization tests for L. $i$. chagasi in wild-caught Proechimys canicollis, the Colombian workers investigated the susceptibility of another spiny rat, Proechimys semispinosus, to experimental infection with $L$. $i$. chagasi by the intracardial and intradermal inoculation of promastigotes (Travi et al. 2002). No parasites could be isolated from these spiny rats by the periodic culture of liver aspirates, but at autopsy they were isolated in cultures of splenic material from $5 / 10$ of the animals. No parasites could be found in stained spleen smears, however, and repeated xenodiagnosis $(L u$. longipalpis) failed to reveal parasites. Finally, PCR-hybridization examination of skin (ears) were all negative.
The authors concluded that "The inability to infect $P$. semispinosus experimentally with $L$. chagasi indicates that it is not highly susceptible to this Leishmania species...."; that ".... L. chagasi infection in Proechimys semispinosus is contained and compartmentalized."; and that "Proechimys canicollis, which is naturally infected with L. chagasi in Northern Colombia, may be a more capable reservoir host than P. semispinosus"

During studies on leishmaniasis in the Amazon region of north Brazil by workers in the Instituto Evandro Chagas, a total of 2637 wild animals were examined for leishmanial infection, including rodents, marsupials, procyonids, canids and edentates (Lainson et al. 1987): this list in-

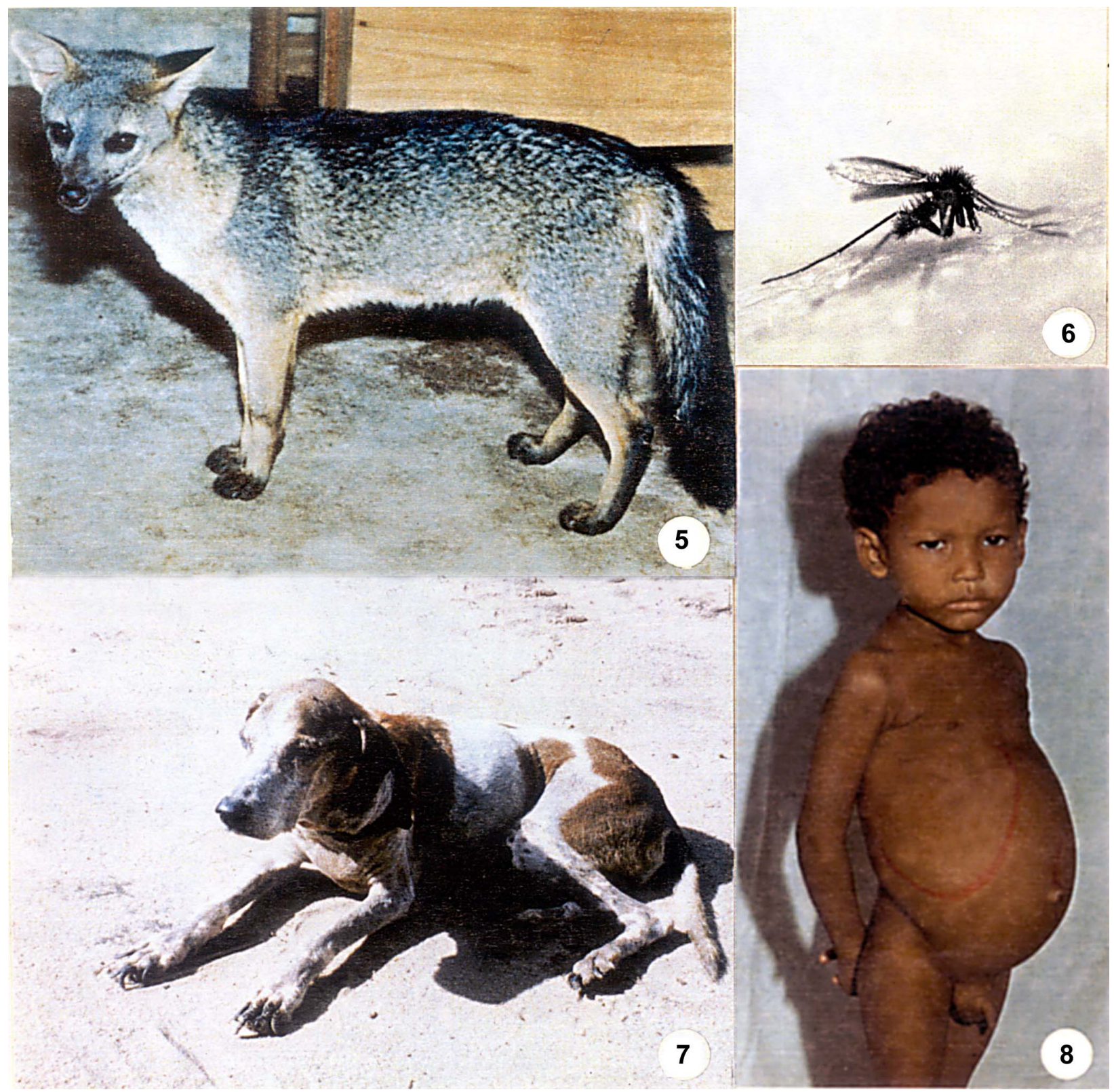

Figs 5-8: four fundamental factors in the establishment of a focus of Amazonian visceral leishmaniasis in the state of Pará, Brazil. Fig. 5: a natural reservoir host of the causative parasite Leishmania infantum chagasi, the fox Cerdocyon thous. Fig. 6: the sandfly vector Lutzomyia longipalpis. Fig. 7: infected domestic dogs, which become the major source of human infection (Fig. 8). 
cluded large numbers of the opossum D. marsupialis and the spiny rat $P$. guyannensis, many of which were captured near the houses of patients with AVL and, in the case of opossums, frequently in the backyards of such houses. No infections with L. i. chagasi were detected in any animal other than the fox $C$. thous, following the culture of spleen and liver tissue and the inoculation of this material intraperitineally into hamsters. At the time of these studies the PCR/hybridization technique had not been developed and, in view of the finding of Travi et al. (1998b) that tissues of wild-caught $P$. canicollis gave a positive PCR to L. i. chagasi DNA in Colombia, Lainson et al. (2002) examined the susceptibility of laboratory-bred $P$. guyannensis to experimental infection with a canine strain of L. i. chagasi from north Brazil. The animal proved to be totally resistant to infection by way of promastigotes and amastigotes after massive intraperitoneal inoculation of the parasite, and subsequent PCR/hybridization tests made on liver and spleen tissue were negative. This, failure in attempts to feed laboratory-bred Lu. longipalpis on $P$. guyannensis or to capture this sandfly in traps baited with the rodent and placed in or near houses infested by Lu. longipalpis, led to the conclusion that this species of spiny rat plays no part in the eco-epidemiology of AVL in north Brazil.
At the 3rd World Congress on Leishmaniasis in April, 2005, workers at the Adolfo Lutz Institute, São Paulo, Brazil, presented the results of an examination of wild animals for evidence of Leishmania infections in two localities of endemic cutaneous leishmaniasis in the state of São Paulo. Each animal was examined by “.....one or more of the following methods: detection of rK39 antibody in whole blood; intradermal inoculation of hamsters with skin biopsies from lesions and/or hipocromic spots or culture and/or DNA extraction for PCR and RFLP tests". Among the positive results were " $L$. $(L$.) chagasi in 1 Akodon sp. and 2 D. marsupialis". Unfortunately, the published abstract of the presentation (Tolezano et al. 2005) does not indicate by which method these results were obtained or, more importantly, if the parasite was isolated from these three animals.

The finding of a benign infection of $L$. i. chagasi in marsupials and rodents similar to that commonly found in foxes, does tend to support the hypothesis that the parasite is indigenous to the Americas, in spite of genomic evidence to the contrary (Mauricio et al. 1999). Of greater importance, however, is the fact that it raises the question as to what extent these animals may act as reservoirs of infection for the sandfly vector and thus play a role in the epidemiology of human AVL.

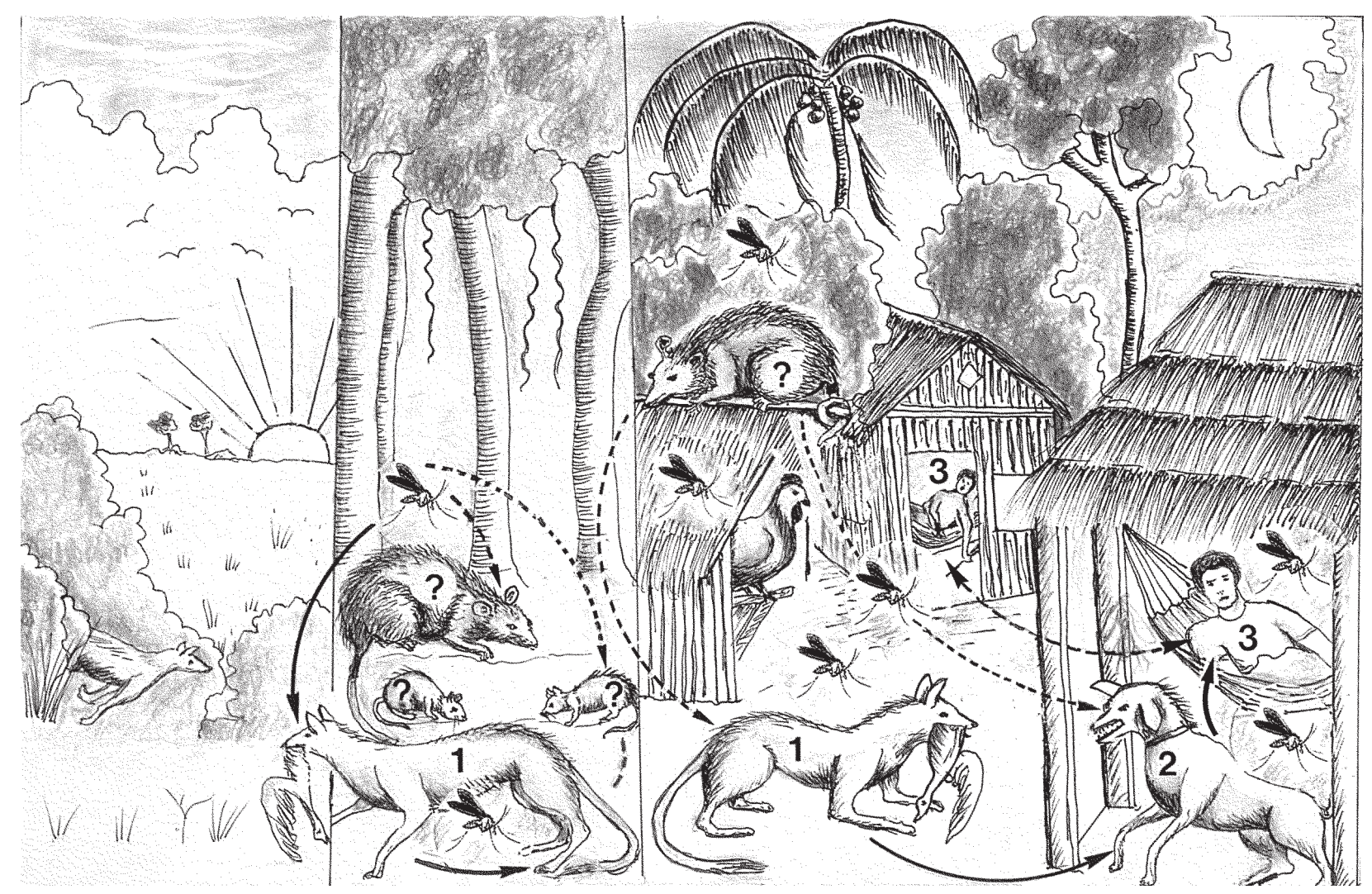

Fig. 9: suggested eco-epidemiology of American visceral leishmaniasis in the state of Pará, North Brazil. The parasite L. i. chagasi, originating from a silvatic enzootic in foxes and possibly other wild animals (1), is maintained by a silvatic population of the sandfly Lutzomyia longipalpis. Invasion of dwelling places on the edge of the forest by this sandfly enables the establishement of canine and human infection $(2,3)$, and the domestic dog now becames the major source of the parasite. Unbroken lines indicate definite routes of transmission. Broken lines represent possible transmission with other wild animals, and possibly man himself, serving as a source of infection for sandflies (Modified from Lainson, 1989). 
An effective reservoir-host of any parasite is one which can participate in the maintenance and dissemination of that parasite in nature, and when parasites are dependant on haematophagous vectors for their transmission it is clearly necessary to show that these can be infected when fed on the host in question. Until this is done the infected animal is best referred to as a potential reservoir. The isolation of $L$. $i$ chagasi from numerous specimens of the fox C. thous and the opossum D. marsupialis, and the experimental infection of Lu. longipalpis fed on these animals, places them firmly in the category of natural reservoirs of L. i. chagasi (Lainson et al. 1990, Travi et al. 1998a). On the other hand, although positive results of PCR tests on the tissues of some wild rodents do suggest that these may also represent reservoirs, isolation of the parasite and experimental infection of $\mathrm{Lu}$. longipalpis fed on the infected animals are needed to confirm this.

\section{Control}

In the areas of high endemicity, such as in the northeastern states of Brazil, past attempts to control visceral leishmaniasis had the form of a three-pronged attack, with the treatment of patients, destruction of infected dogs and regular insecticide spraying of houses (Deane 1956). Although this effectively reduced the number of human cases of AVL, the system was costly and could rarely be maintained for a sufficiently long period to totally eliminate the disease and, with recent criticism of culling infected dogs, the control of AVL still presents a serious problem for the health authorities throughout the vast geographic range of the causative parasite.

Destruction of serologically and parasitologically positive dogs - Although this may temporarily affect the cumulative incidence of seroconversion in these animals and may also diminish the incidence of human cases of AVL (Ashford et al. 1998), it inevitably meets with opposition on the part of dog owners, who understandably find it difficult to see why their apparently healthy (but serologically positive) dogs are condemned to death. For this reason, dogs tend to be hidden during control measures; there is the constant problem of innumerable strays, and there remains the potential danger of new or revitalized foci of AVL from the wild animal enzootic. Mathematical models regarding the three methods of control (Dye 1996) suggest that the destruction of serologically positive dogs is far less likely to solve the problem of AVL than insecticide spraying or (if and when available) the vaccination of these animals (Tesh 1995).

Vaccination of dogs - An efficient vaccine would be of immense help in the control of AVL and its application could coincide with anti-rabies vaccination, thus cutting the costs considerably. Preliminary experiments with a vaccine prepared from $L$. (V.) braziliensis combined with BCG gave promise (Mayrink et al. 1996), but the Phase III trials led to the conclusion that the vaccine "did not appear to protect the dogs against visceral leishmaniasis" (Genaro et al. 1996). The "Fucose-Mannose ligand" (FML), a complex glycoproteic fraction isolated from an aqueous extract of $L$. (L.) donovani, has been used in conjunction with a saponin adjuvant in attempts to vaccinate dogs against $L$. i. chagasi (Silva et al. 2000). The authors regarded the vaccine as a promising tool in the control of canine visceral leishmaniasis in endemic areas of AVL. However, the Brazilian Ministry of Health is still not using this vaccine in the National Programme for Control of Visceral Leishmaniasis.

Use of insecticides - The development of chemical insecticides in the 1940's resulted in extensive use of DDT against mosquito vectors of malaria and this, at the same time, had a fortuitous and dramatic effect on the peridomestic sandfly vectors of visceral leishmaniasis, in particular in the endemic areas of kala-azar due to $L$. $(L$.) donovani in India. In Brazil it was first used in the 1950s to spray the internal and external walls of houses in the state of Ceará, specifically to combat AVL, and it resulted in a considerable reduction in the number of cases in some localities (Deane et al. 1955, Deane 1958, Alencar 1961, 1962). In others, however, there were perplexingly poor results which were probably due to a failure to apply the insecticide at the right time of year (Alencar 1961).

In spite of evidence militating against the use of DDT, due to both environmental side effects and human health hazards, this insecticide was still recommended as the one of choice by the World Health Organization up to 1990, because of its low cost, high efficacy and long residual action (WHO 1990). It is still used to this day in Brazil, but attention has now been focused on the synthetic pyrethroids. Although some have described the results as rather inconsistent (Silans et al. 1998), Le Pont et al. (1989), and Marcondes and Nascimento (1993) found the spraying of deltamethrin (DM) to be effective against $L u$. longipalpis in Bolivia and Brazil, respectively.

A novel approach to the control of canine visceral leishmaniasis due to L. i. infantum in the Cévennes, Southern France, utilized PVC plastic dog collars impregnated with deltamethrin (Killick-Kendrick et al. 1997). The collars protected dogs from $96 \%$ of the bites of sandflies (laboratory-bred Phlebotomus perniciosus) and this activity was maintained for up to 34 weeks. It was concluded that "at least in the Mediterranean subregion, this insecticidal collar would protect a dog from the majority of sandfly bites and retain a killing effect for a complete sandfly season. Moreover, it seems likely that the use of the collars on all dogs in a focus of $L$. infantum would reduce contact between sandfly vectors and canine reservoir hosts sufficiently to diminish the risk of infection in humans as well as dogs". DM treatment of dogs by way of an aqueous bath has been found to be highly effective in protecting the animals against sandfly bites in China (Xiong et al. 1994, 1995). DM impregnated collars have been used in the same country (Chen et al. 2001), Italy (Maroli et al. 2001), and Brazil (David et al. 2001, Reithinger et al. 2004). Among the great advantages of DM is its repellant and killing action of long duration No side effects have been detected, and it is considered to offer no human or canine health risk (WHO 1967). Following the results of field trials with DM impregnated dog collars in Brazil, it would seem that an extensive and governmentally managed programme for the control of canine AVL in Latin America might well utilize either this 
method or the periodic bathing of dogs in aqueous solutions of the insecticide.

\section{Biological control}

In addition to Leishmania, Trypanosoma, and Endotrypanum spp., and possibly other trypanosomatids, neotropical sandflies may harbour other parasites including microsporidians (Lainson et al. 1977b), gregarines (Adler \& Mayrink 1961, Ayala 1971, Brazil et al. 1996, Lewis et al. 1970), some Plasmodium spp. of lizards (Klein et al. 1987), and even nematodes (Brazil \& Ryan 1984). There is little information on the pathological effects these parasites may produce in their sandfly hosts, but the gregarine Ascogregarina chagasi is known to reduce longevity and egg production and can effectively destroy a laboratory colony of Lu. longipalpis (Dougherty \& Ward 1991): microsporidial infection may sometimes be extremely heavy, and these parasites are known to be highly pathogenic in some insects (Kudo 1960). To what extent $A$. chagasi and microsporidian spp., could be employed in biological control of wild populations of sandflies, particularly $L u$. longipalpis, is questionable. One serious obstacle to such control is that the precise locality of the breeding sites of sandfly vectors of both visceral and cutaneous leishmaniasis are poorly known. When these are in the forest, application of biological control is likely to be particularly difficult and possibly of environmental risk.

\section{Epilogue}

The present-day enzootology and epidemiology of AVL as seen in the more remote parts of Latin America possibly represents a recapitulation of what transpired when the early colonists first commenced their ecological upheavals. Native animals harbour $L$. i. chagasi as an enzootic maintained by sylvatic sandflies (Lu. longipalpis and/or $\mathrm{Lu}$. evansi) and the parasite inevitably gains entrance into newly established human settlements. This may be by way of infected sandflies that migrate there from the nearby sylvatic enzootic, or when infected scavengers such as foxes or opossums invade human habitations and are fed on by the sandflies from peridomestic populations. Transmission of the parasite to dogs or man is then only a question of time and a single infected dog, often with a vast supply of amastigotes for these sandflies in its skin, sets the scene for a small focus of canine or human visceral leishmaniasis. When human habitations become overcrowded, with conditions of poor hygiene and an abundance of domestic animals, particularly dogs, the concentration of the vector Lu. longipalpis (and/or Lu. evansi in some parts of Latin America) may reach a very high level and there is the risk of a serious outbreak of canine and human disease. At this stage of events the dog becomes the major reservoir of infection for man, and the wild animal host may, in fact, no longer be present in the immediate area. Control measures in such foci of infection will certainly reduce the number of human cases of AVL but, unfortunately, total elimination of the disease is unlikely, due to a persistent source of L. i. chagasi in the wild animal enzootic - a problem equally difficult to resolve in control of the cutaneous leishmaniases.

\section{REFERENCES}

Adler S, Mayrink W 1961. A gregarine, Monocystis chagasi n.sp., of Phlebotomus longipalpis. Remarks on the accessory glands of P. longipalpis. Rev Inst Med Trop São Paulo 3: $230-238$.

Aguilar CM, Fernández E, Cannova DC, Ferrer E, Cabrera Z, Souza WJS, Coutinho SG 1998. Urban visceral leishmaniasis in Venezuela. Mem Inst Oswaldo Cruz 93: 15-16.

Alencar JE 1961. Profilaxia do calazar no Ceará, Brasil. Rev Inst Med Trop São Paulo 3: 175-180.

Alencar JE 1962. Kala-azar in Brazil. Sci Rep Inst Sup Sanitá 2: $116-123$.

Alexander JB 1987. Dispersal of phlebotomine sandflies in a Colombian coffee plantation. J Med Entomol 24: 552-558.

Arrivillaga JC, Feliciangeli MD 2001. Lutzomyia pseudolongipalpis, the first new species within the longipalpis (Diptera: Psychodidae: Phlebotominae) complex from Rinconada, Curarigua, Lara State, Venezuela. J Med Entomol 38: 783-790.

Arrivillaga JC, Rangel Y, Oviedo M, Feliciangeli MD 2000. Genetic diversity among Venezuelan populations of Lutzomyia longipalpis (Diptera:Psychodidae: Phlebotominae). J Med Entomol 37: 325-330.

Arrivillaga JC, Norris DE, Feliciangeli MD, Lanzaro GC 2002. Phylogeography of the neotropical sand fly Lutzomyia longipalpis inferred from mitochondrial DNA sequences. Inf Gen Evol 2: 83-95.

Arrivillaga J, Mutebi JP, Pinango H, Norris D, Alexander B, Feliciangeli MD, Lanzaro GC 2003. The taxonomic status of genetically divergent populations of Lutzomyia longipalpis (Diptera: Psychodidae) based on the distribution of mitochondrial and isozyme variation. J Med Entomol 40: 615-627.

Ashford DA, David JR, Freire M, David R, Sherlock I, Eulalio M, Sampaio DP, Badaró R 1998. Studies on control of visceral leishmaniasis: impact of dog control of canine and human visceral leishmaniasis in Jacobina, Bahia, Brazil. Am J Trop Med Hyg 59: 53-57.

Ayala SC 1971. Gregarine infections in the Californian sandfly, Lutzomyia vexatrix occidentis. J Invert Path 17: 440-441.

Azevedo ACR, Monteiro FA, Cabello PH, Souza NA, RosaFreitas MG, Rangel EF 2000. Studies on populations of Lutzomyia longipalpis (Lutz \& Neiva, 1912) (Diptera: Psychodidae: Phlebotominae) in Brazil. Mem Inst Oswaldo Cruz 95: 305-322.

Bauzer LGSR, Souza NA, Ward RD, Kyriacou CP, Peixoto AA 2002. The period gene and genetic differentiation between three Brazilian populations of Lutzomyia longipalpis. Insect Mol Biol 11: 315-323.

Bottecchia M, Oliveira SG, Bauzer LGSR, Souza NA, Ward RD, Garner KJ, Kyriacou CP, Peixoto AA 2004. Genetic divergence in the cacophony IVS6 Intron among five Brazilian populations of Lutzomyia longipalpis. J Mol Evol 58: 754-761.

Brazil RP, Ryan L 1984. Nota sobre a infecção de Lutzomyia evandroi (Diptera: Psychodidae) por Ascocystis chagasi (Adler \& Mayrink, 1961) no Estado do Maranhão. Mem Inst Oswaldo Cruz 79: 375-376. 
Brazil RP, Oliveira SMP, Dias CMG, Andrade JD, Falcão AL 1996. Natural infection of New World phlebotomine sandflies (Diptera:Psychodidae) with Ascogregarina. Mem Inst Oswaldo Cruz 91 (Suppl.): 116.

Chagas AW 1940. Criação de flebótomos e transmissão experimental da leishmaniose visceral americana. Mem Inst Oswaldo Cruz 35: 327-333.

Chagas E 1936. Primeira verificação em individuo vivo, da leishmaniose visceral no Brasil. Bras-Méd 50: 221-222.

Chagas E, Cunha AM, Ferreira LC, Deane L, Deane G, Guimarães FN, Paumgartten MJ, Sá B 1938. Leishmaniose visceral americana (Relatório dos trabalhos realizados pela Commissão Encarregada do Estudo da Leishmaniose Visceral Americana em 1937). Mem Inst Oswaldo Cruz 33: 89229.

Chen S, Li F, He J, Chen X, Wang D, Wei L, Yang H, Guan L 2001. Experimental study on prevention of dog-sand fly contact by Deltamethrin collar. End Dis Bull 16: 17-19.

Coelho MV, Cunha AS, Falcão AR 1965. Notas sobre um foco de calazar no sudoeste do Estado de Goiás. Rev Bras Malariol Doenças Trop 17: 143-148.

Corredor A, Gallego JF, Tesh RB, Peláez D, Diaz A, Montilla M, Paláu MT 1989a. Didelphis marsupialis, an apparent wild reservoir of Leishmania donovani chagasi in Colombia, South America. Trans R Soc Trop Med Hyg 83: 195.

Corredor A, Gallego JF, Tesh RB, Morales A, Ferro de Carrasquilla C, DG, Kreutzer RD, Boshell J, Paláu MT, Caceres E, Peláez D 1989b. Epidemiology of visceral leishmaniasis in Colombia. Am J Trop Med Hyg 40: 480-486.

Courtenay O, Santana EW, Johnson PJ, Vasconcelos IAB, Vasconcelos AW 1996. Visceral leishmaniasis in the hoary zorro Dusicyon vetulus: a case of mistaken identity. Trans R Soc Trop Med Hyg 90: 498-502.

Crampton J, Knapp T, Ward RD 1989. DNA probes for vector taxonomy. In DDT Hart, Leishmaniasis. The Current Status and New Strategies for Control, NATO ASI Series A: Life Sci 163 Plenum Press \& NATO Scientific Affairs Division, New York and London, p. 957-964.

Cunha AM, Chagas E 1937. Nova espécie de protozoário do gênero Leishmania patogênico para o homem. Leishmania chagasi n.sp. Nota Prévia. Hospital (Rio de Janeiro) 11: 3-9.

David JR, Stamm LM, Bezerra HS, Souza RN, Killick-Kendrick R, Lima JWO 2001. Deltamethrin-impregnated dog collars have a potent anti-feeding and insecticidal effect on Lutzomyia longipalpis and Lutzomyia migonei. Mem Inst Oswaldo Cruz 96: 839-847.

Deane LM 1956. Leishmaniose Visceral no Brasil. Serviço Nacional de Educação Sanitária, Rio de Janeiro, p. 1-162.

Deane LM 1958. Epidemiologia e profilaxia do calazar americano. Rev Brás Malariol 10: 431-450.

Deane MP, Deane LM 1954a. Infecção natural do Phlebotomus longipalpis por leptomonas, provavelmente de Leishmania donovani, em foco de calazar, no Ceará. Hosptital (Rio de Janeiro) 45: 697-702.

Deane LM, Deane MP 1954b. Encontro de leishmanias nas vísceras e na pele de uma raposa, em zona endêmica de calazar, nos arredores de Sobral, Ceará. Hospital (Rio de Janeiro) 45: 419-421.
Deane MP, Deane LM. 1954c. Infecção experimental do Phlebotomus longipalpis em raposa (Lycalopex vetulus) naturalmente parasitada pela Leishmania donovani. Hospital (Rio de Janeiro) 46: 651-653.

Deane LM, Grimaldi G 1985. Leishmaniasis in Brazil. In KP Chang, RS Bray (eds), Leishmaniasis, Elsevier, Amsterdam, p. $247-281$.

Deane LM, Deane MP, Alencar JE 1955. Observações sobre o combate ao Phlebotomus longipalpis pela dedetização em área endêmica de calazar no Ceará. Rev Bras Malariol 7: 131-141.

Decker-Jackson FE, Tang DB 1982. Identification of Leishmania spp. By radiorespirometry. II. A statistical method of data analysis to evaluate the reproductibility and sensitivity of the technique. In ML Chance, BC Walton (eds), Biochemical Characterization of Leishmania, proceedings of a workshop held at the PanAmerican Health Organization, Geneva, p. 205-245.

Dougherty MJ, Ward RD 1991. Methods of reducing Ascogregarina chagasi parasitaemia in laboratory colonies of Lutzomyia longipalpis. In Proceedings of the First International Symposium on Phlebotomine Sandflies, Rome. Parassitologia (Roma) 33: 185-191.

Dujardin JP, Torrez EM, Le Pont F, Hervas D, Sossa D 1997. Isozymic and metric variation in the Lutzomyia longipalpis complex. Med Vet Entomol 11: 394-400.

Dye C 1996. The logic of visceral leishmaniasis control. Am J Trop Med Hyg 55: 125-130.

Dye C, Davies CR, Lainson R 1991. Communication among phlebotomine sandflies: a field study of domesticated Lutzomyia longipalpis populations in Amazonian Brazil. Animal Behaviour 42: 183-192.

Feliciangeli MD, Arrivillaga JC, Bravo A, Arias F 2004. Activity of Lutzomyia pseudolongipalpis and L. longipalpis s.1. (Diptera: Psychodidae) in Venezuela. Parasite 11: 273-278.

Feliciangeli MD, Rodriguez N, De Guglielmo Z, Rodriguez A 1999. The re-emergence of American visceral leishmaniasis in an old focus in Venezuela. II. Vectors and parasites. Parasite 6: 113-120.

Ferro C, Morrison AC, Torres M, Pardo R, Wilson ML, Tesh RB 1995. Age structure, blood-feeding behaviour, and Leishmania chagasi infection in Lutzomyia longipalpis (Diptera: Psychodidae) at an endemic focus of visceral leishmaniasis in Colombia. J Med Ent 32: 618-629.

Galati EAB, Nunes VLB, Cristaldo G, Rocha HC 2003. Aspectos do comportamento da fauna flebotomínea (Diptera:Psychodidae) em foco de leishmaniose visceral e tegumentar na Serra da Bodoquena e área adjacente, Estado de Mato Grosso do Sul, Brasil. Rev Pat Trop 32: 235-261.

Genaro O, Pinto JA, Costa CA, França-Silva JC, Costa RT, Silva JC, Sanguinetti LSR, Vieira EP, Toledo VPCP, Mayrink W 1996. Phase III randomized double blind clinical trial on the efficacy of a vaccine against canine visceral leishmaniasis in urban area of Montes Claros, MG, Brazil. Mem Inst Oswaldo Cruz 91 (Suppl.): 166.

Hamilton JGC, Ward RD, Dougherty R, Maingon C, Ponce E, Noyes H, Zelodón R 1996. Comparison of the sex-pheromone components of Lutzomyia longipalpis from areas of visceral and atypical cutaneous leishmaniasis in Honduras and Costa Rica. Ann Trop Med Parasitol 90: 533-541. 
Hodgkinson VH, Birungi J, Quintana M, Deitze R, Munstermann LE 2003. Mitochondrial cytochrome B variation in populations of the visceral leishmaniasis vector Lutzomyia longipalpis across eastern Brazil. Am J Trop Med Hyg 69: 386-392.

Ibáñez-Bernal S, Rodríguez-Domínguez G, Gómez-Hernández $\mathrm{CH}$, Ricardez-Esquinc JR 2004. First record of Lutzomyia evansi (Nuñez-Tovar 1924) in México (Diptera: Psychodidae: Phlebotominae). Mem Inst Oswaldo Cruz 99: 127129.

Imms AD 1964. A General Textbook of Entomology, Methuen \& Co Ltd, London, EP Dutton \& Co Inc., New York, 886 pp.

Jackson PR, Wohlhieter J, Hockmeyer WT 1982. Leishmania characterization by restriction endonuclease digestion of kinetoplastic DNA. In Abstr Vth Internat Congr Parasitol Toronto, Canada, p. 342.

Jackson PR, Stiteler JM, Wohlhieter JA, Reed SG, Badaró R, Inverso JA, Jackson JE 1984. Characterization of Leishmania responsible for visceral disease in Brazil by restriction endonuclease digestion and hybridization of kinetoplast DNA. In Proc 11th Internat Congr Trop Med Malar Calgary, Canada, p. 68.

Killick-Kendrick R 1985. Some epidemiological consequences of the evolutionary fit between leishmaniae and their phlebotomine vectors. Bull Soc Path Exot 78: 747-755.

Killick-Kendrick R, Killick-Kendrick M, Focheux C, Dereure J, Puech M-P, Cadiergues MC 1997. Protection of dogs from the bites of phlebotomine sandflies by deltamethrin collars for control of canine leishmaniasis. Med Vet Ent 11: 105-111.

Klein TA, Young DG, Telford SR, Kimsey R 1987. Experimental transmission of Plasmodium mexicanum by bites of infected Lutzomyia vexator (Diptera: Psychodidae). J Am Mosq Contr Assoc 3: 154-164.

Kudo RR 1960. Protozoology, Charles C Thomas, Springfield, Illinois, $966 \mathrm{pp}$.

Lainson R 1989. Demographic changes and their influence on the epidemiology of the American leishmaniases. In M Service, Demography and Vector Borne Diseases, CRC Press, Boca Raton, FL, p. 85-106.

Lainson R, Rangel EF 2003. Ecologia das leishmanioses: Lutzomyia longipalpis e a eco-epidemiologia da leishmaniose visceral americana (LVA) no Brasil. In EF Rangel, R Lainson (eds), Flebotomíneos do Brasil, Fiocruz, Rio de Janeiro, p. 311-336.

Lainson R, Shaw JJ 1979. The role of animals in the epidemiology of South American leishmaniasis. In WHR Lumsden, DA Evans (eds), Biology of the Kinetoplastida, Vol. 2, Academic Press, London, p. 1-116.

Lainson R, Shaw JJ 1987. Evolution, classification and geographic distribution. In W Peters, R Killick-Kendrick (eds), The Leishmaniases in Biology and Medicine, Vol. 1, Academic Press, London, p. 1-120.

Lainson R, Shaw JJ 1998. New World leishmaniasis - the neotropical Leishmania species. In L Collier, A Balows, M Sussman (eds), Topley \& Wilson's Microbiology and Microbial Infections, Vol. 5, Parasitology. Arnold, London, p. 241-266.
Lainson R, Shaw JJ 2005. Leishmaniasis in the New World. In L Collier, A Balows, M Sussman (eds), Topley \& Wilson's Microbiology and Microbial Infections, 10th ed., Vol 5, Parasitology, Arnold, London, p. 313-349.

Lainson R, Ishikawa EAY, Silveira FT 2002. American visceral leishmaniasis: wild animal hosts. Trans $R$ Soc Trop Med Hyg 96: 630-631.

Lainson R, Miles MA, Shaw JJ 1981. On the identification of viscerotropic leishmanias. Ann Trop Med Parasitol 75: 251253.

Lainson R, Shaw JJ, Lins CZ 1969. Leishmaniasis in Brazil, IV. The fox, Cerdocyon thous (L.) as a reservoir of Leishmania dovovani in Pará State, Brazil. Trans R Soc Trop Med Hyg 63: 741-745.

Lainson R, Ward RD, Shaw JJ 1977a. Experimental transmission of Leishmani chagasi causative agent of neotropical visceral leishmaniasis, by the sandfly Lutzomyia longipalpis. Nature (London) 266: 628-630.

Lainson R, Killick-Kendrick R, Canning EU, Shaw JJ, Ward RD, Leaney AJ Nicholas JP 1977b. Microsporidia of Brazilian sandflies. Trans $R$ Soc Trop Méd Hyg 71: 381.

Lainson R, Shaw JJ, Ryan L, Ribeiro RSM, Silveira FT 1984. Presente situação da leishmaniose visceral na Amazônia, com especial referência a um novo surto da doença ocorrido em Santarém, Estado do Pará, Brasil. Bol Epidemiol F.SESP, Rio de Janeiro (número especial): 1-8.

Lainson R, Shaw JJ, Ryan L, Silveira FT 1985. Leishmaniasis in Brazil XXI. Visceral leishmaniasis in the Amazon Region and further observations on the role of Lutzomyia longipalpis (Lutz \& Neiva, 1912) as the vector. Trans $R$ Soc Trop Med Hyg 79: 223-226.

Lainson R, Shaw JJ, Silveira FT, Braga RR 1987. American visceral leishmaniasis: on the origin of Leishmania (Leishmania) chagasi. Trans R Soc Trop Med Hyg 81: 517.

Lainson R, Shaw JJ, Silveira FT, Braga RR, Ryan L, Povoa MM, Ishikawa EAY 1986. A Leishmania e as leishmanioses. In Instituto Evandro Chagas: 50 Anos de Contribuição às Ciências Biológicas e à Medicina Tropical, Vol. I, Serviços de Saúde Pública, Belém, Pará, p. 83-124.

Lainson R, Dye C, Shaw JJ, MacDonald DW, Courtenay O, Souza AAA, Silveira FT 1990. Amazonian visceral leishmaniasis - Distribution of the vector Lutzomyia longipalpis (Lutz \& Neiva) in relation to the fox Cerdocyon thous (Linn) and the efficiency of this reservoir host as a source of infection. Mem Inst Oswaldo Cruz 85: 135-137.

Lainson R, Shaw JJ, Silveira FT, Souza AAA, Braga RR, Ishikawa EAY 1994. The dermal leishmaniases of Brazil, with special reference to the eco-epidemiology of the disease in Amazonia. Mem Inst Oswaldo Cruz 89: 435-443.

Lampo M, Torgerson D, Márquez LM, Rinaldi M, Garcia CZ, Arab A 1999. Occurrence of sibling species of Lutzomyia longipalpis (Diptera: Psychodidae) in Venezuela: first evidence from reproductively isolated sympatric populations. Am J Trop Med Hyg 61: 1004-1009.

Lane R, Phillips A, Molyneux DH, Procter G, Ward RD 1985. Chemical analysis of the abdominal glands of two forms of Lutzomyia longipalpis: site of a possible sex pheromone? Ann Trop Med Parasitol 79: 225-229.

Lanzaro GC, Ostrovska K, Herrero MV, Lawyer PG, Warburg 
A 1993. Lutzomyia longipalpis is a species complex: genetic divergence and interspecific hybrid sterility among three populations. Am J Trop Med Hyg 48: 839-847.

Le Pont F, Padilla J, Dejeux P, Richard A, Mouchet J 1989. Impact de pulverizations de deltametrine dans un foyer de leishmaniose de Bolivie. Ann Soc Belge Méd Trop 69: 223232.

Lerner EA, Ribeiro JMC, Nelson RJ, Lerner M 1991. Isolation of Maxadilan, a potent vasodilatory peptide from the salivary glands of the sandfly Lutzomyia longipalpis. J Biol Chem 266: 11234-11236.

Lewis DJ, Lainson R, Shaw JJ 1970. Determination of parous rates in phlebotomine sandflies, with special reference to Amazon species. Bull Ent Res 60: 209-219.

Lutz A, Neiva A 1912. Contribuição para o conhecimento das espécies do gênero Phlebotomus existentes no Brasil. Mem Inst Oswaldo Cruz 4: 84-95.

Lysenko AJ 1971. Distribution of leishmaniasis in the Old World. Bull WHO 44: 515-520.

Maingon RD, Ward RD, Hamilton JG, Noyes HA, Souza N, Kemp SJ, Watts PC 2003. Genetic identification of two sibling species of Lutzomyia longipalpis (Diptera: Psychodidae) that produce distinct male sex pheromones in Sobral, Ceara State, Brazil. Mol Ecol 12: 1879-1894.

Mangabeira O 1969. Sobre a sistemática e biologia dos Phlebotomus do Ceará. Rev Bras Malariol Doenças Trop 21: 326.

Marcondes CB, Nascimento JA 1993. Avaliação de eficiência de deltametrina (K-Othrine CE) no controle de Lutzomyia longipalpis (Diptera: Psychodidae), no município de Santa Rita, Paraíba, Brasil. Rev Soc Bras Med Trop 26: 15-18.

Maroli M, Mizzoni V, Siragusa C, D’Orazi A, Gradoni L 2001. Evidence for an impact on the incidence of canine leishmaniasis by the mass use of deltamethrin-impregnated dog collars in southern Italy. Med Vet Ent 15: 358-363.

Martinez E, Alonso V, Quispe A, Thomas MC, Alonso R, Piñero JE, González AC, Ortega A, Valladares B 2003. RAPD method useful for distinguishing Leishmania species: design of specific primers for L. braziliensis. Parasitology 127: 513-517.

Martins AV, Williams P, Falcão AL 1978. American Sand Flies, Acad Bras Ciências, Rio de Janeiro, 195 pp.

Martins AV, Falcão AL, Silva JE, Dias ES 1984. Nota sobre Lutzomyia (Lutzomyia) cruzi (Mangabeira, 1938), com a descrição da fêmea (Diptera, Psychodidae, Phlebotominae). Mem Inst Oswaldo Cruz 79: 439-442.

Mauricio IL, Howard MK, Stothard JR, Miles MA 1999. Genomic diversity in the Leishmania donovani complex. Parasitology 119: 237-246.

Mayrink W, Genero O, Silva JCF, Costa RT, Tafuri WL, Toledo VPCP, Silva AR, Reis AB, Williams P, Costa CA 1996. Phase I and II open clinical trials of a vaccine against Leishmania chagasi infection in dogs. Mem Inst Oswaldo Cruz, 91: 695-697.

Mello DA, Rego FA, Oshozo E, Nunes VLB 1988. Cerdocyon thous (L.) (Carnivora: Canidae) naturally infected with Leishmania chagasi (Cunha \& Chagas, 1937) in Corumbá (Mata Grosso do Sul State, Brazil). Mem Inst Oswaldo Cruz 83: 259.
Montoya-Lerma J, Cadena H, Oveido M, Ready PD, Barazarte R, Travi BL, Lane RP 2003. Comparative vectorial efficiency of Lutzomyia evansi and L. longipalpis for transmitting Leishmania chagasi. Acta Trop 85: 19-29.

Morton I, Ward RD 1989. Laboratory responses of female Lutzomyia longipalpis sandflies to a host and male pheromone source over distance. Med Vet Ent 3: 219-223.

Mukhopadhyay J, Ghosh K, Rangel EF, Munstermann LE 1998. Genetic variability in biochemical characters of Brazilian field populations of the Leishmania vector, Lutzomyia longipalpis (Diptera: Psychodidae). Am J Trop Med Hyg 59: 893-901.

Mutebi JP, Alexander B, Sherlock I, Wellington J, Souza AA, Shaw J, Rangel EF, Lanzaro GC 1999. Breeding structure of the sand fly Lutzomyia longipalpis (Lutz \& Neiva) in Brazil. Am J Trop Med Hyg 61: 149-157.

Mutebi JP, Tripet F, Alexander JB, Lanzaro GC 2002. Genetic differentiation among populations of Lutzomyia longipalpis (Diptera: Psychodidae) in Central and South America. Ann Entomol Soc Amer 95: 740:752.

Oliveira AC, Batista SM, Falcão AL 1959. Calazar em Minas Gerais. Revisão dos dados epidemiológicos obtidos até 1958. Hospital (Rio de Janeiro) 56: 625-643.

Oliveira MP, Grimaldi G, Momen H, Pacheco RS, Marzochi MCA, McMahon-Pratt D 1986. Active cutaneous leishmaniasis in Brazil, induced by Leishmania donovani chagasi. Mem Inst Oswaldo Cruz 81: 303-309.

Paraense L, Chagas AW 1940. Transmissão experimental da leishmaniose visceral americana pelo Phlebotomus intermedius. Nota prévia. Bras Med 54: 179-180.

Penna HA 1934. Leishmaniose visceral no Brasil. Bras Med 48: 949-950.

Perdeck AC 1957. The isolating value of specific song patterns in two sibling species of grasshoppers (Chorthippus brunneus Thumb and C. biguttulus L.). Behaviour 12: 175 .

Pífano CF, Romero MJ 1964. Comprobación de um nuevo foco de leishmaniose em Venezuela, Valle de Cumanacoa, Edo. Sucre. Gac Méd Caracas 72: 473-479.

Ponce C, Ponce E, Morrison A, Cruz A, Kreutzer R, McMahonPratt D, Neva F 1991. Leishmania donovani chagasi: new clinical variant of cutaneous leishmaniasis in Honduras. Lancet 337: 67-70.

Potenza L, Anduze J 1942. Kala-azar en el Estado de Bolívar, Venezuela. Rev Policlín (Caracas) 11: 312-317.

Quinnell RJ, Dye C 1994a. An experimental study of the peridomestic distribution of Lutzomyia longipalpis (Diptera: Psychodidae). Bull Ent Res 84: 379-382.

Quinnell RJ, Dye C 1994b. Correlates of the domestic abundance of Lutzomyia longipalpis (Diptera: Psychodidae) in Amazonian Brazil. Med Vet Ent 8: 219-224.

Rangel EF, Lainson R 2003. Ecologia das leishmanioses. Transmissores de leishmaniose tegumentar Americana. In EF Rangel, R Lainson (eds), Flebotomíneos do Brasil, Fiocruz, Rio de Janeiro, p. 291-309.

Ready PD, Lainson R, Shaw JJ, Souza AA 1991. DNA probes for distinguishing Psychodopygus wellcomei from 
Psychodopygus complexus (Diptera: Psychodidae). Mem Inst Oswaldo Cruz 86: 41-49.

Reithinger R, Coleman PG, Alexander B, Vieira EP, Assis G, Davies CR 2004. Are insecticide-impregnated dog collars a feasible alternative to dog culling as a strategy for controlling visceral leishmaniasis in Brazil? Int J Parasitol 34: 55-62.

Rioux JA, Lanotte G, Serres E, Pratlong F, Bastien P, Perieres J 1990. Taxonomy of Leishmania. Use of isoenzymes. Suggestions for a new classification. Ann Parasitol Hum Comp 65: 111-125.

Ryan L, Lainson R, Shaw JJ 1986a. The experimental transmission of Leishmania mexicana amazonensis Lainson \& Shaw, between hamsters by the bite of Lutzomyia furcata (Mangabeira). Trans R Soc Trop Med Hyg 80: 164-165.

Ryan L, Lainson R, Shaw JJ 1987. Leishmaniasis in Brazil. XXIV. Natural flagellate infections of sandflies (Diptera: Psychodidae) in Pará State, with particular reference to the role of Psychodopygus wellcomei as the vector of Leishmania brazilienisis braziliensis in the Serra dos Carajás. Trans $R$ Soc Trop Med Hyg 81: 353-359.

Ryan L, Silveira FT, Lainson R, Shaw JJ 1984. Leishmanial infections in Lutzomyia longipalpis and Lu. antunesi (Diptera: Psychodidae) on the island of Marajó, Pará State, Brazil. Trans R Soc Trop Med Hyg 78: 547-548.

Ryan L, Lainson R, Shaw JJ, Fraiha H 1986c. Ecologia de flebotomíneos (Diptera: Psychodidae: Phlebotominae) na Região Amazônica. In Instituto Evandro Chagas: 50 Anos de Contribuição às Ciências Biológicas e à Medicina Tropical, Vol. I, Serviços de Saúde Pública, Belém, Pará, p. $307-$ 320 .

Ryan L, Phillips RA, Milligan P, Lainson R, Molyneux DH, Shaw JJ 1986b. Separation of female Psychodopygus wellcomei and Ps. complexus (Diptera: Psychodidae) by cuticular hydrocarbon analysis. Acta Trop 43: 85-89.

Santoro F, Lemesre JL, Rizvi FS, Afchain D, Sadogirsky M 1986. Spécificité au niveau de protéines de surface des promastigotes de Leishmania donovani (Laveran et Mesnil, 1903), Leishmania infantum Nicolle, 1908 et Leishmania chagasi Cunha et Chagas, 1937. In JA Rioux (2-6 July, 1984). Leishmania. Taxonomie et Phylogenése. Aplications eco-Épidemiologiques. Montpellier, France: Colloque Internat, IMMEE, p. 71-76.

Santos SO, Arias J, Ribeiro AA, Hoffmann MP, Freitas RA, Malacco MAF 1998. Incrimination of Lutzomyia cruzi as a vector of American visceral leishmaniasis. Med Vet Ent 12: 315-317.

Santos SO, Arias JR, Hoffmann MP, Furlan MBG, Ferreira WF, Pereira C, Ferreira L 2003. The presence of Lutzomyia longipalpis in a focus of American visceral leishmaniasis where the only proven vector is Lutzomyia cruzi, Corumbá, Mato Grosso do Sul State. Rev Soc Bras Med Trop 36: 633-634.

Sherlock IA, Miranda JC, Sadigursky M, Grimaldi G 1984. Natural infection of the opossum Didelphis albiventris (Marsupialia: Didelphidae) with Leishmania donovani in Brazil. Mem Inst Oswaldo Cruz, 79: 511.

Sherlock IA, Miranda JC, Sadigursky M, Grimaldi G 1988. Observações sobre calazar em Jacobina, Bahia. VI. Investigações sobre reservatórios silvestres e comensais.
Rev Soc Bras Med Trop 21: 23-27.

Silans LNMP, Dedet J-P, Arias JR 1998. Field monitoring of cypermethrin residua effect on the mortality rates of the phlebotomine sand fly Lutzomy longipalpis in the state of Paraíba, Brazil. Mem Inst Oswaldo Cruz 93: 339-344.

Silva VO, Borja-Cabrera GP, Correia Pontes NN, Souza EP, Luz KG, Palatinik M, Palatinik de Souza CD 2000. A Phase III trial of efficacy of the FML-vaccine against canine calazar in an endemic area of Brasil (São Gonçalo do Amarante, RN). Vaccine 19: 1082-1092.

Silveira FT, Lainson R, Shaw JJ, Póvoa MM 1982. Leishmaniasis in Brazil: XVIII. Further evidence incriminating the fox Cerdocyon thous (L.) as a reservoir of Amazonian visceral leishmaniasis. Trans $R$ Soc Trop Med Hyg 76: 830832.

Soto SI, Lehmann T, Rowton ED, Velez BID, Porter CH 2001. Speciation and population structure in the morphospecies Lutzomyia longipalpis (Lutz and Neiva) as derived from the mitochondrial ND4 gene. Mol Phylogenet Evol 18: 84-93.

Souza MB, Marzochi MCA, Carvalho RW, Ribeiro PC, Pontes CS, Caetano JM, Meira AM 2003. Ausência da Lutzomyia longipalpis em algumas áreas de ocorrência de leishmaniose visceral no Município do Rio de Janeiro. Cad Saúde Púb 19: 1881-1885.

Souza NA, Vigoder FM, Araki AS, Ward RD, Kyriacou CP, Peixoto AA 2004. Analysis of the copulatory courtship songs of Lutzomyia longipalpis in six populations from Brazil. J Med Entomol 41: 906-913.

Tesh RB 1995. Control of zoonotic visceral leishmaniasis: is it time to change strategies? Am J Trop Med Hyg 52: 287-292.

Tolezano JE, Taniguchi HH, Araújo MF, Cunha EA, ChioccolaVLP, Pirmez C, Shaw JJ 2005. Evidence of different Leishmania enzootic cycles, especially L. (Viannia) braziliensis, in two endemic American cutaneous leishmaniasis (ACL) regions of São Paulo State, Brazil. Abstract Book, Third World Congress on Leishmaniasis, 10-15 April, 2005. Palermo-Terrasini, Sicily, Italy, p. 213.

Torrealba JW, Torrealba JF 1964. Infección experimental de Cerdocyon thous (zorro común) com Leishmania donovani. Gac Méd Caracas 72: 117-118.

Travi BL, Arteaga LT, Leon AP, Adler GH 2002. Susceptibility of spiny rats (Proechimys semispinosus) to Leishmania (Viannia) panamensis and Leishmania (Leishmania) chagasi. Mem Inst Oswaldo Cruz, 97: 887-892.

Travi BL, Jaramillo C, Montoya J, Segura I, Zea A, Goncalves A, Vélez ID 1994. Didelphis marsupialis, an important reservoir of Trypanosoma cruzi and Leishmania (Leishmania) chagasi in Colombia. Am J Trop Med Hyg 50: 557565.

Travi BL, Montoya J, Gallego J, Jaramillo C, Llano R, Vélez ID 1996. Bionomics of Lutzomyia evansi (Diptera: Psychodidae), vector of visceral leishmaniasis in Northern Colombia. J Med Entomol 33: 278-285.

Travi BL, Osorio Y, Becerra MT, Adler GH 1998b. Dynamics of Leishmania chagasi infection in small mammals of the undisturbed and degraded tropical dry forests of northern Colombia. Trans R Soc Trop Med Hyg 92: 275-278.

Travi BL, Osório Y, Guarin N, Cadena H 1998a. Leishmania (Leishmania) chagasi: clinical and parasitological observa- 
tions in experimentally infected Didelphis marsupialis, reservoir of New World visceral leishmaniasis. Exp Parasitol 88: 73-75.

Travi BL, Vélez ID, Brutus L, Segura I, Jaramillo C, Montoya J 1990. Lutzomyia evansi, an alternative vector of Leishmania chagasi in a Colombian focus of visceral leishmaniasis. Trans $R$ Soc Trop Med Hyg 84: 676-677.

Uribe S 1999. The status of the Lutzomyia longipalpis species complex and possible implications for Leishmania transmission. Mem Inst Oswaldo Cruz 94: 729-734.

Warburg A, Saraiva E, Lanzaro GC, Titus RG, Neva F 1994. Saliva of Lutzomyia longipalpis sibling species differs in its composition and capacity to enhance leishmaniasis. Phil Trans $R$ Soc Lond Serie B 345: 223-230.

Ward RD, Ribeiro AL, Ready PD, Murtagh A 1983. Reproductive isolation between different forms of Lutzomyia longipalpis (Lutz \& Neiva) (Diptera: Psychodidae), the vector of Leishmania donovani chagasi Cunha \& Chagas and its significance to kala-azar distribution in South America. Mem Inst Oswaldo Cruz 78: 269-280.

Ward RD, Phillips A, Burnet B, Marcondes CB 1988. The Lutzomyia longipalpis complex: reproduction and distribution. In MW Service, Biosystematics of Haematophagus Insects, Clarendon Press, Oxford, p. 257-269.

Ward RD, Ribeiro AL, Ryan L, Falcão AL, Rangel EF 1985. The distribution of two morphological forms of Lutzomyia longipalpis (Lutz \& Neiva) (Diptera: Psychodidae). Mem Inst Oswaldo Cruz 80: 145-148.
Watts PC, Hamilton JG, Ward RD, Noyes HA, Souza NA, Kemp SJ, Feliciangeli MD, Brazil R, Maingon RD 2005. Male sex pheromones and the phylogeographic structure of the Lutzomyia longipalpis species complex (Diptera: Psychodidae) from Brazil and Venezuela. Am J Trop Med Hyg 73: 734-743.

WHO-World Health Organization 1967. Safe use of pesticides in Public Health. Tech Rep Series 356, Geneva.

WHO-World Health Organization 1990. Control of Leishmaniasis. Tech Rep Series 793, Geneva, 158 pp.

Xiong G, Jin C, Cheng X, Su Z 1994. Deltamethrin bath of domestic dog in the prevention of sandfly bite. End Dis Bull 9: 32-34.

Xiong G, Jin C, Hong Y, Su Z 1995. Studies on the deltamethrin -medicated bath of domestic dogs for interrupting visceral leishmaniasis transmission. Chinese J Parasitol \& Parasit Dis 13: 178-181.

Yin H, Mutebi JP, Marriott S, Lanzaro GC 1999. Metaphase karyotypes and G-banding in sand flies of the Lutzomyia longipalpis complex. Med Vet Entomol 13: 72-77.

Young DG, Duncan MA 1994. Guide to the identification and geographic distribution of Lutzomyia sandflies in Mexico, the West Indies, Central and South America (Diptera: Psychodidae). Mem Am Entomol Inst 54: 881 pp.

Zeledón R, Hidalgo H, Viquez A, Urbina A 1989. Atypical cutaneous leishmaniasis in a semi-arid region of north-west Costa Rica. Trans R Soc Trop Med Hyg 83: 789. 
